Vol. 23, No. 4, pp. 324 338, 2020.

\title{
Artificial Photosynthesis for Value-Added Chemicals Production
}

\author{
Seongje Lim, Kwang Hee Kim, Sungsoon Kim, Jong Hyeok Park ${ }^{\dagger}$
}

Department of Chemical and Biomolecular Engineering, Yonsei University Seoul 03722, Republic of Korea

\section{인공 광합성 기술 기반 고부가가치 물질 생산 시스템}

\author{
임성제, 김광희, 김성순, 박종혁 \\ 연세대학교 화공생명공학과
}

(Received November 16 2020; Revised December 9 2020; Accepted December 10 2020)

\begin{abstract}
s
Solar energy utilization has been drawn attention due to the environmental issues. Photoelectrochemical and photocatalytic water splitting for hydrogen production, which is well-known solar-to-chemical process, have been studied so far, however it is now facing limitations of efficiency along with affordable cost. Recently, research trends in artificial photosynthesis are changing their redox reaction to produce value-added chemicals. Thanks to the previously studied solar water splitting technologies and materials, value-added chemicals production by solar energy is now evolving rapidly by taking advantages from the established works. Here, we introduce various kinds of redox reactions for producing value-added chemicals via photoelectrochemical and photocatalytic process. Throughout the article, solar-driven redox reactions such as $\mathrm{CO}_{2}$ reduction, $\mathrm{H}_{2} \mathrm{O}_{2}$ production are comprehensively discussed from the fundamentals to the applications. Consequently, future perspectives are suggested, which may help put forward future commercialization of photoelectrochemical or photocatalytic value-added chemical production technologies.
\end{abstract}

Keywords: Artificial photosynthesis, Photoelectrochemical cell, Photocatalyst, Value-added chemicals production, Redox reactions

${ }^{\dagger}$ Corresponding Author: Jong Hyeok Park

E-mail: lutts@yonsei.ac.kr 


\section{1. 서론}

전 세계적으로 에너지 및 환경 문제가 대두됨에 따라, 신 에너지 기술로서 태양 에너지를 활용한 기술에 대한 관심이 높아지고 있다. 그중 인공 광합성 기술은 이산 화탄소와 물을 산소와 포도당으로 전환하는 자연 광합 성을 모사하여 광에너지를 화학에너지로 전환하는 기술 로, 태양광을 이용하여 물 분해를 통한 수소 및 산소 발 생 반응이 주로 연구되어 왔다. ${ }^{1-6)}$ 인공 광합성 기술의 에너지 전환 효율은 다음과 같이 표현할 수 있는데,

$$
n=\frac{\Delta G \times R}{P_{\text {sun }} \times S}
$$

이때 $\Delta G$ 는 목표 반응의 깁스 자유 에너지 변화, $R$ 은 반응 속도, $P_{\operatorname{sun}}$ 은 태양광의 전력 밀도(power density), $S$ 는 태양광이 조사되는 면적을 의미한다. ${ }^{7,8)}$ 일반적으로 물 분해 반응에서는 $10 \%$ 이상의 전환 효율을 가질 때 경 제적으로 효용이 있는 것으로 간주되는데, 물 분해 반응 의 $\Delta G$ 는 $237 \mathrm{~kJ} \mathrm{~mol}^{-1}$ 로 일정하므로 인공 광합성 기술 의 에너지 전환 효율 극대화를 위해서는 최대한 높은 반 응 속도 $(\mathrm{R})$ 를 필요로 한다.

광전기화학시스템 $(\mathrm{PEC})$ 및 광촉매 $(\mathrm{PC})$ 를 이용한 물 분해 반응은 저항 전압 손실(ohmic loss) 없이 광 자 에너지를 화학 에너지로 직접 전환시킴으로써 적 은 비용으로도 인공 광합성이 가능하다는 장점을 가 지고 있어 큰 관심을 받고 있다. 인공 광합성 시스템 에서 높은 반응 속도를 얻기 위해서는 넓은 범위의 빛 수확 능력, 효율적인 전하 분리, 빠른 표면 반응성 등 의 조건을 만족시키는 반도체 소재가 필요하다. 하지 만 여러 소재들, 특히 자연에 널리 존재하는 값싼 소 재들은 이러한 조건들을 모두 만족시킬 수 없기 때문 에 기존 시스템 내에서 원하는 전환 효율을 얻기 힘들 다는 한계를 가지고 있다. 예를 들어, 인공 광합성 반 도체 소재로 널리 사용되는 $\mathrm{TiO}_{2}$ 는 넓은 밴드 갭(band gap)으로 인해 태양광 스펙트럼에서 3 5\%에 해당하 는 자외선 영역의 빛 만을 흡수할 수 있기 때문에 효 율이 매우 낮다. ${ }^{9-11)}$ 이외에도 $\mathrm{BiVO}_{4}$ 와 $\mathrm{g}-\mathrm{C}_{3} \mathrm{~N}_{4}$ 는 느
린 표면 물 산화 반응 속도, $\mathrm{Cu}_{2} \mathrm{O}$ 와 $\mathrm{CdS}$ 는 반응 중의 낮은 안정성 등의 단점을 가지고 있기 때문에 이론적 으로 얻을 수 있는 최대 효율을 달성하기 위해서는 추 가적인 개선 방안이 필요하다. ${ }^{12-18)}$ 따라서, 산질화물 (oxynitride) $^{19,20)}$, 산황화물(oxysulfide) $)^{21)}$ 등의 새로 운 소재의 도입과 이종 접합(heterojunction) ${ }^{22,23)}$, 도핑 (doping) $)^{24,25)}$, 계면 개질(interface engineering) ${ }^{26,27)}$, 나노 구조화(nanoengineering) ${ }^{28)}$, 조촉매(co-catalyst loading $)^{29,30)}$ 등의 개선방안을 통해 이론적인 최대 전환 효율을 달성하기 위한 연구들이 진행되어 왔다.

최근에는 이미 알려진 인공 광합성 반도체 소재를 사 용하여 기존의 물 분해 반응을 대체하는 다른 산화 . 환원 반응을 통해 고부가가치 물질을 생산함으로써 더 큰 경제적인 효용을 얻어내기 위한 연구가 진행되고 있 다. ${ }^{31-36)}$ 이러한 인공 광합성 기반 고부가가치 물질 생산 시스템은 기존의 물 분해 반응에 비해 훨씬 높은 경제 적 가치를 가지고 있어 인공 광합성 기술 분야에서 많은 주목을 받고 있다. 예를 들어, $\mathrm{TiO}_{2}, \mathrm{Cu}_{2} \mathrm{O}, \mathrm{Si}$ 등 기존 의 물 분해 시스템에서 널리 사용되던 소재들을 이용하 여 물 환원 반응 대신 이산화탄소 환원 반응을 통해 다 양한 가치 있는 탄화수소들을 얻는 것이 가능하며 ${ }^{33,37-}$ 39), 물 산화 반응을 통한 산소 발생 반응 대신 20 배 이 상의 경제적 가치를 가지는 과산화수소 생성 반응을 도 입함으로써 전체 시스템의 경제적 효용을 크게 증가시 킬 수 있다. ${ }^{32)}$ 인공 광합성 기반 고부가가치 물질 생산 시스템의 다양한 산화 · 환원 반응은 물 분해 반응과 경 쟁 관계에 있으므로, 각 생성 반응에 대한 높은 선택도 (selectivity) 및 반응에 적합한 에너지 레벨을 가지는 반도체 소재 선택 등의 시스템 설계가 필요하다. 새로 운 산화 - 환원 반응의 도입을 통한 고부가가치 물질 생 산 시스템은 에너지 전환 효율을 크게 향상시켜 에너지 환경 문제 해결에 대한 가능성을 제공할 수 있을 것으로 기대된다.

본 논문에서는 인공 광합성 기반 고부가가치 물질 생 산 시스템에 대해 소개하고자 한다. 먼저 인공 광합성 기술의 기본적인 개념 및 효율 향상을 위한 개선 방향에 대해 소개하고, 두 번째로 이산화탄소 환원, 산소 환원, 


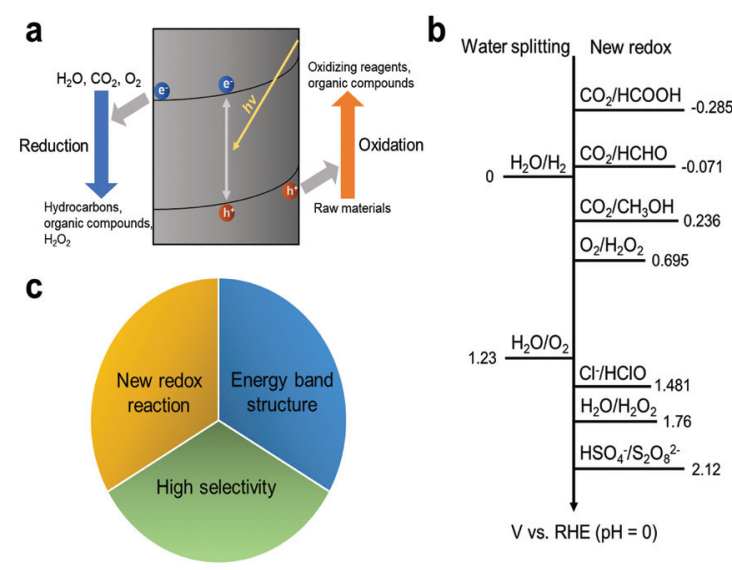

Fig. 1. a) Schematic illustration of PEC system with various redox reactions. b) Schematic illustration of redox potentials of water splitting and various chemical production. c) Schematic illustration of three strategy to improve economical value of artificial photosynthesis system.

산화제 생산, 유기 합성 등의 인공 광합성 기반 고부가 가치 화합물 생산 시스템 및 에너지 전환 효율과 선택도 를 향상시키기 위한 다양한 전략들을 소개한다. 마지막 으로 앞으로의 인공 광합성 기반 고부가가치 물질 생산 시스템의 해결 과제 및 전망에 대해 논하고자 한다.

\section{2. 인공 광합성 기술의 개요 및 개선 방안}

기존의 인공 광합성 기반 물 분해 반응은 수소 발생 반응(HER)과 산소 발생 반응(OER)으로 구성되며 이론 적으로 $1.23 \mathrm{~V}$ 이상의 표준 전위차를 필요로 한다. 그 러나 실제 물 분해 반응에는 활성화 과전압 등의 추가적 인 에너지 손실이 존재하기 때문에 반응에 사용되는 반 도체 소재는 최소 $2.3 \mathrm{eV}$ 이상의 밴드 갭을 가져야 한 다. 이러한 물 분해 반응을 통해 수소와 산소가 생성되 는데, 수소는 경제적으로 높은 가치가 있음에 반해 산소 는 경제적 가치를 가지지 않기 때문에 전체 시스템의 경 제적 가치는 한계점을 가질 수밖에 없다. 이러한 전체 시스템의 경제적인 문제를 해결할 수 있는 전략 중 하나 가 바로 기존의 반응을 다른 반응으로 교체함으로써 고 부가가치 물질을 생산할 수 있는 시스템을 설계하는 것 이다(Fig. 1 (a)). 다시 말해, 물 분해 반응에서 수소 발
생 반응, 산소 발생 반응을 새로운 산화 - 환원 반응으로 대체함으로써 탄화수소, 과산화수소, 유기 화합물, 산화 제 등 고부가가치 물질 생산을 가능하게 하여 결과적으 로 전체 시스템의 경제적 가치를 높이는 것이다. 대표적 으로 환원 반응을 통해서는 고가의 탄화수소, 유기 화합 물, 과산화수소 등이, 산화 반응을 통해서는 다양한 산 화제, 유기 화합물 등이 생산될 수 있다. 적용 가능한 다 양한 산화 · 환원 반응의 예와 그 환원 전위가 Fig. 1 (b) 에 제시되어 있다. 하지만 이러한 반응들이 실제로 시스 템에 도입되기 위해서는 반응에 사용되는 반도체 소재 가 열역학적 조건을 만족해야 한다. 즉, 인공 광합성 시 스템에 사용되는 반도체 소재가 해당 반응에 적합한 밴 드 갭을 가지고 있어야 한다. 특히 $\mathrm{PC}$ 시스템의 경우 $\mathrm{PEC}$ 시스템과 달리 외부 전압이 가해지지 않으므로 원 하는 전체 산화 - 환원 반응에 필요한 표준 전위차 및 과 전압을 모두 포함하는 높은 밴드 갭을 가지는 반도체 소 재를 선택해야 한다.

인공 광합성의 전환 효율을 높이기 위해서는 높은 R 값, 즉 빠른 반응 속도를 가져야 하기 때문에 목표 반응 에 대한 선택도를 높여 반응 속도를 향상시키는 것 또 한 중요하다. 목표 반응에 대한 선택도를 높이기 위한 개선 방안으로는 (1) 조촉매, (2) 반응 속도 제어, (3) 표 면 화학 구조 제어 등이 있다. 인공 광합성 기술에 사용 되는 반도체 소재들은 금속 기반 소재에 비해 느린 표 면 반응성을 가지고 있는데 조촉매를 첨가함으로써 표 면 반응 속도를 향상시킬 수 있다. ${ }^{40)}$ 또한 반도체 소재 의 밴드 구조상 다수의 반응이 동시에 가능한 경우에는 각 반응에 대한 반응 속도가 목표 반응의 선택도를 좌우 한다. ${ }^{41,42)}$ 목표 산화 - 환원 반응의 경쟁 반응인 물 분해 반응은 작은 $\triangle G$ 와 활성화 에너지를 가지기 때문에 빠 른 반응 속도를 가지므로 목표 반응에 대한 선택도를 높 이기 위해서는 이를 억제해야 한다. 마지막으로 반도체 소재의 표면 화학 구조 또한 반응 경로에 영향을 주기 때문에 목표 반응에 대한 선택도에 영향을 준다. ${ }^{43)}$ 따라 서, 위와 같은 개선 방안을 통해 원하는 고부가가치 물 질 생산 반응에 대한 반응 속도 및 선택도를 높이고, 전 체 시스템의 높은 전환 효율을 달성하여 미래의 인공 광 
합성 기술 상용화에 더욱 다가설 수 있다(Fig. 1 (c)).

\section{3. 환원 반응 기반 교부가가치 물질 생산 시스템}

\section{1 이산화탄소 환원 반응}

이산화탄소는 화석 연료의 연소로 인해 발생하는 대 표적인 물질로 대기로 방출되어 온실 효과를 발생시키 기 때문에, 이산화탄소를 탄화수소 또는 연료로 전환하 는 이산화탄소 재활용 방안에 대한 연구들이 진행되고 있다. ${ }^{44)}$ 이산화탄소는 가장 높은 산화수의 탄소를 가지 고 있어 환원 반응을 통해 다양한 종류의 물질들을 생산 할 수 있다. 그러나 이산화탄소의 $\mathrm{C}=\mathrm{O}$ 이중 결합을 끊 기 위해서는 높은 에너지 $\bigcirc 750 \mathrm{~kJ} \mathrm{~mol}^{-1}$ )가 필요하기 때 문에 이산화탄소의 흡착 및 활성화를 위해 추가적인 조 촉매의 도입에 대한 연구가 진행되었다. Halmann이 처 음으로 $\mathrm{p}-\mathrm{GaP}$ 광환원전극과 탄소 산화전극을 이용한 $\mathrm{PEC}$ 시스템을 통해 이산화탄소를 메탄올, 폼산, 폼알 데하이드로 전환한 연구를 보고한 이래로, 조촉매를 도 입하여 이산화탄소 환원 반응의 생성물에 대한 선택도 를 높이기 위해 많은 연구들이 진행되었다. ${ }^{45)}$ Yin 연구 팀은 $\mathrm{Cu}-\mathrm{Zn}$ 합금을 조촉매로 도입한 $\mathrm{SrTiO}_{3}(\mathrm{STO})$ 나 노 입자를 이용하여 이산화탄소를 선택적으로 폼산으로 전환하였다(Fig. 2 (b)). ${ }^{46)}$ 이산화탄소 환원 반응 경로는 환원 중간체와 촉매 표면과의 흡착 강도에 의존하는데, $\mathrm{Cu}-\mathrm{Zn}$ 합금에서의 $\mathrm{Cu}$ 와 $\mathrm{Zn}$ 의 구성 비율 조절에 따른 이산화탄소의 흡착 강도 제어를 통해 이산화탄소를 선 택적으로 폼산으로 전환할 수 있었다.

Tseng 연구팀은 $\mathrm{Cu}$ 가 담지 된 $\mathrm{TiO}_{2}$ 에 피크 파장이 $254 \mathrm{~nm}$ 인 자외선을 조사하여 이산화탄소를 메탄올로 전환하였다. ${ }^{47)} \mathrm{Cu}$ 는 전자와 정공의 재결합을 억제하 고 $\mathrm{CO}_{2}$ 환원 반응을 위한 활성 부위를 제공하여 $\mathrm{Cu}$ 가 $2 \mathrm{wt} \%$ 포함된 $\mathrm{Cu}-\mathrm{TiO}_{2}$ 광촉매의 경우 20 시간 동안 $250 \mu \mathrm{mol} \mathrm{g}{ }_{\text {cat }}{ }^{-1}$ 의 메탄올 생산 속도를 보였다. Cheng 연구팀은 $\mathrm{Pt}-\mathrm{rGO}$ 를 환원전극으로 사용하고, $\mathrm{Pt}-\mathrm{TiO}_{2}$ 를 광산화전극으로 사용하여 이산화탄소 환원 반응과 물 산화 반응을 결합한 $\mathrm{PEC}$ 시스템을 설계하였다. ${ }^{48)}$ $\mathrm{Pt}-\mathrm{rGO}$ 는 다양한 광환원전극과 비교하였을 때 빠른 전
자 이동 및 높은 반응 흡착 부위를 가지기 때문에 높은 이산화탄소 전환율을 보였다. 또한 본 시스템에서 생성 된 메탄올과 표면에 흡착되어 있는 메틸렌 작용기의 상 호작용을 통해 에탄올이 생성되었으며, 고차 탄화수소 에 대한 뛰어난 선택도를 가진 $\mathrm{Cu}$ 를 도입함으로써 에탄 올 생성 반응에 대한 선택도를 증가시켰다.

이산화탄소 환원 반응을 통해 폼산, 메탄올, 에탄올 등의 액체 생성물 뿐만 아니라 메테인, 일산화탄소 등 의 기체 생성물 역시 얻을 수 있다. ${ }^{49-53)}$ 이산화탄소 환 원 반응을 통한 메테인 전환 반응은 $818 \mathrm{~kJ} \mathrm{~mol}^{-1}$ 로 매 우 높은 $\Delta G$ 와 8 개의 전자 이동을 포함하는 반응이 다. 따라서, 메테인 전환 반응은 양성자 결합 전자 전달 (proton-coupled electron transfer, PCET) 반응을 통 한 여러 단계의 복잡한 반응이 수반되어야 한다. Wang 연구팀은 다목적 기상증착법을 통해 제작된 $\mathrm{Pt}-\mathrm{TiO}_{2}$ 나 노 구조 필름을 사용하여 $1,361 \mu \mathrm{mol} \mathrm{g} \mathrm{cat}^{-1} \mathrm{~h}^{-1}$ 의 메테 인 생산 속도와 높은 선택도를 얻었다(Fig. 2 (a)). ${ }^{54)}$ 넓 은 표면적을 가지는 단결정 $\mathrm{TiO}_{2}$ 필름에 $0.5 \sim 2 \mathrm{~nm}$ 의 $\mathrm{Pt}$ 나노 입자를 조촉매로 첨가함으로써 효율적으로 전 자-정공 쌍을 분리하였고, Pt 나노 입자에 전자가 고립 되어 다 전자 반응(multi-electron reaction)의 발생 빈 도가 증가함으로써 메테인 생성 반응에 대한 선택도가 향상되었다. Neaţu 연구팀은 $\mathrm{Au}-\mathrm{Cu}$ 합금 나노 입자로 개질 된 $\mathrm{P} 25 \mathrm{TiO}_{2}$ 를 사용하여 이산화탄소를 메테인으 로 전환하였다. ${ }^{55)} \mathrm{Au}$ 의 플라즈모닉 효과로 인해 가시광 선 영역에서의 반응성이 향상되었으며, $\mathrm{Cu}$ 가 이산화탄 소 환원 반응에 대한 활성 부위로 작용하여 선택도가 향 상되었다(Fig. 2 (c)). 결과적으로 $\mathrm{Au}-\mathrm{Cu}$ 합금 나노 입 자로 개질 된 $\mathrm{P} 25 \mathrm{TiO}_{2}$ 는 메테인 생성 반응에 대해 2.2 $\mathrm{mmol} \mathrm{g} \mathrm{g}^{-1} \mathrm{~h}^{-1}$ 의 생산 속도와 $97 \%$ 의 선택도를 보였다.

이러한 인공 광합성 기반 이산화탄소 환원 시스템에 더해, 환원전극 및 산화전극을 모두 광전극으로 사용하 는 적층형 $\mathrm{PEC}$ 시스템은 효율적인 전자-정공 쌍 분리 가 가능하고 추가적인 전압이 필요하지 않기 때문에 높 은 전환 효율을 얻을 수 있다는 장점을 가지고 있다. ${ }^{56,57)}$ Wang 연구팀은 $\mathrm{TiO}_{2} / \mathrm{Ni}$ 광환원전극과 $\mathrm{BiVO}_{4}$ 광산화전 극을 결합하여 이산화탄소 환원 반응과 물 산화 반응이 
동시에 발생하는 시스템을 설계하였고, $153 \mu \mathrm{mol} \mathrm{h}{ }^{-1}$ $\mathrm{cm}^{-2}$ 의 메테인 생산 속도를 달성하였다. ${ }^{58)}$ Gong 연구 팀은 $\mathrm{a}-\mathrm{Si} / \mathrm{TiO}_{2} / \mathrm{Au}$ 광환원전극과 $\mathrm{BiVO}_{4}$ 광산화전극을 사용하여 일산화탄소와 수소의 비율을 조절 가능한 합 성가스를 생산하였다. ${ }^{59)}$ 광환원전극에 조촉매로 사용된 $\mathrm{Au}$ 는 일산화탄소 전환 반응에 대해 높은 효율과 선택도 를 가지는데, $\mathrm{Au}$ 에 존재하는 결정립계의 조절을 통해 이산화탄소 환원 반응의 · $\mathrm{COOH}$ 중간체를 효과적으로 안정시켜 일산화탄소 생성 반응에 대한 선택도를 향상 시켰다. 또, $\mathrm{Au}$ 의 두께 변화에 의한 결정립계의 조절을 통해 생산되는 합성가스의 일산화탄소와 수소의 비율을 조절하였다.

이처럼 이산화탄소 환원 반응과 물 산화 반응이 결합 된 인공 광합성 시스템에 대한 연구가 진행되어왔다. 하
지만, 물 산화 반응의 생성물인 산소는 경제적인 가치 가 거의 없기 때문에 전체 시스템의 경제적 가치를 올리 는 데 한계가 있다. 따라서 물 산화 반응 대신 유기물 산 화 반응을 결합하여 고부가가치의 생성물을 얻음으로써 전체 시스템의 경제적 가치를 향상시키는 것이 중요하 다. Dong 연구팀은 $\mathrm{CsPbBr}_{3}$ 과 $\mathrm{Cs}_{4} \mathrm{PbBr}_{6}$ 로 구성된 페 로브스카이트 소재를 이용하여 이산화탄소 환원과 메탄 올 산화를 결합한 시스템을 설계하였다. ${ }^{60)}$ 또한, $\mathrm{Co}$ 도 핑을 통해 생성된 $\mathrm{Co}-\mathrm{COOH}$ 중간체가 이산화탄소 흡 착을 촉진시키며, $\mathrm{Co} / \mathrm{Co}^{2+}$ 의 환원 전위 $(-0.73 \mathrm{~V} \mathrm{vS.}$ $\mathrm{NHE}$ )가 일산화탄소 생성 반응에 대해 충분한 구동력 을 가지는 것을 확인하였다(Fig. 2 (d)). 이 시스템을 통 해 $1,835 \mu \mathrm{mol} \mathrm{g} \mathrm{cat}^{-1}$ 의 일산화탄소 생산 속도를 얻었으 며, 상대 반응인 메탄올 환원 반응을 통해 폼산이 생산
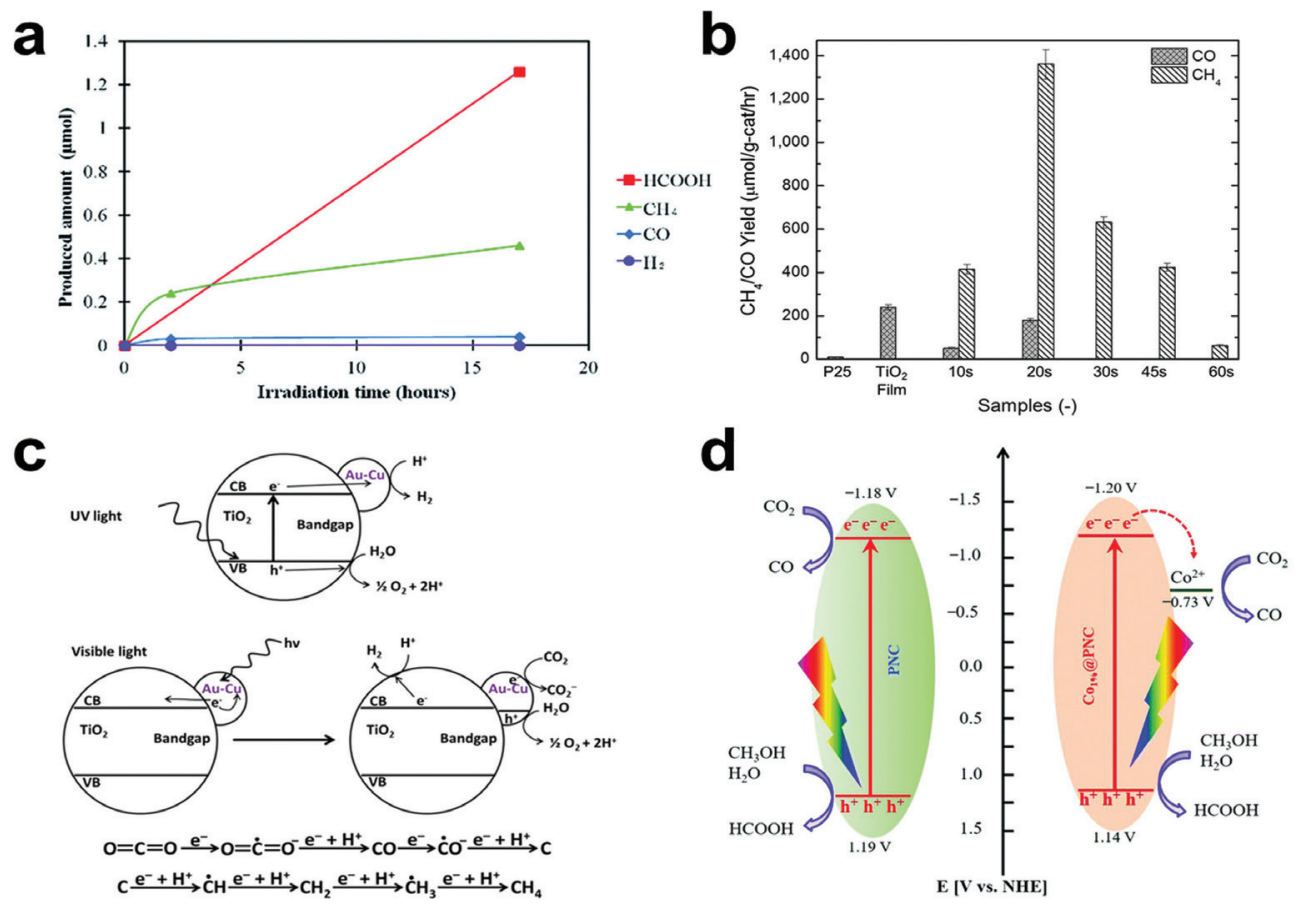

Fig. 2. a) Amounts of produced $\mathrm{HCOOH}, \mathrm{CH}_{4}, \mathrm{CO}$ and $\mathrm{H}_{2}$ via $\mathrm{CO}_{2}$ reduction by $\mathrm{Cu}-\mathrm{Zn}$ alloy nanoparticle-loaded $\mathrm{SrTiO}_{3}$ powders. Reproduced with permission. ${ }^{46)}$ Copyright 2017, The Royal Society of Chemistry. b) $\mathrm{CH}_{4}$ and $\mathrm{CO}$ yield of commercial P25, $\mathrm{TiO}_{2}$ columnar film, and $\mathrm{Pt}-\mathrm{TiO}_{2}$ films with different Pt deposition times. Reproduced with permission. ${ }^{54)}$ Copyright 2012, American Chemical Society. c) Effect of $\mathrm{Au}-\mathrm{Cu}$ nanoalloy on $\mathrm{TiO}_{2}$ photocatalyst according to wavelength range of light. Reproduced with permission. ${ }^{55)}$ Copyright 2014, American Chemical Society. d) Schematic illustration of a $\mathrm{CsPbBr}_{3}$ and $\mathrm{Cs}_{4} \mathrm{PbBr}_{6}$ perovskite nanocomposite with and without $\mathrm{Cu}$. Reproduced with permission. ${ }^{60)}$ Copyright 2020 , The Royal Society of Chemistry. 

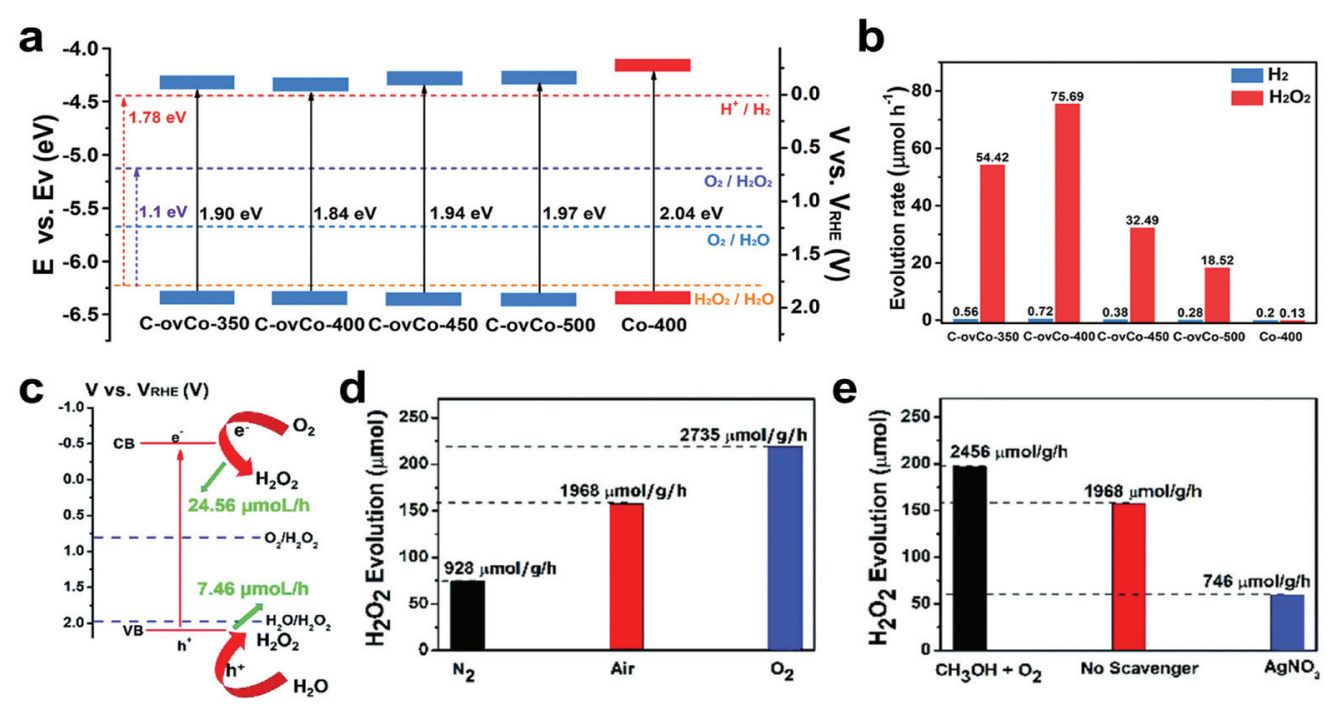

Fig. 3. a) Band structure diagram of $\mathrm{CO}_{3} \mathrm{O}_{4}$ photocatalysts with and without oxygen vacancy. b) $\mathrm{H}_{2}$ and $\mathrm{H}_{2} \mathrm{O}_{2}$ evolution rate of dispersed $20 \mathrm{mg} \mathrm{CO}_{3} \mathrm{O}_{4}$ photocatalysts under visible light irradiation. a, b) Reproduced with permission. ${ }^{62)}$ Copyright 2019, American Chemical Society. c) $\mathrm{H}_{2} \mathrm{O}_{2}$ evolution mechanism of phosphorus-doped porous carbon nitride photocatalyst. $\mathrm{H}_{2} \mathrm{O}_{2}$ evolution rate of phosphorus-doped porous carbon nitride photocatalyst d) with different atmosphere and e) with and without scavengers. c-e) Reproduced with permission. ${ }^{63)}$ Copyright 2020, The Royal Society of Chemistry.

되는 것을 확인하였다. 또한, $\mathrm{Guo}$ 연구팀은 $\mathrm{CdSe} / \mathrm{CdS}$ 양자점 광촉매를 사용하여 이산화탄소 환원 반응과 1페닐에탄올 산화 반응을 결합하였다. ${ }^{61)} \mathrm{CdS}$ 에 황 결핍 을 도입할 경우 활성 부위가 증가하며, 이산화탄소의 일 산화탄소 환원 반응과 1 -페닐에탄올의 피나콜 산화 반 응의 에너지 장벽이 낮아짐으로써 생성물에 대한 높은 선택도 및 생산 속도를 얻었다. 또한 CdS의 두께를 최 적화함으로써 효율적인 전하 분리를 달성하였고, 최적 화된 $\mathrm{CdSe} / \mathrm{CdS}$ 는 일산화탄소 생성 반응에 대한 27.64

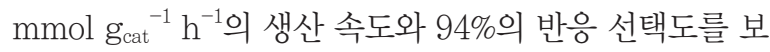
였다. 또한 상대 반응인 1-페닐에탄올 산화 반응을 통해 $26.5 \mathrm{mmol} \mathrm{g}_{\mathrm{cat}}^{-1} \mathrm{~h}^{-1}$ 의 피나콜 생산 속도를 확인하였 다.

\section{2 산소 환원 반응}

산소 환원 반응 역시 높은 부가가치를 지닌 과산화수 소를 생산할 수 있기 때문에 물 분해 반응을 대체할 수 있는 반응으로써 주목받고 있다. 특히 산소 환원 반응은 산소 발생 반응과 결합하여 반응에 필요한 산소를 상대
반응으로부터 공급받는 시스템 뿐만 아니라 과산화수소 를 생산하는 물 산화 반응과 결합하여 산화 - 환원 양 반 응 모두에서 과산화수소를 생산하는 시스템으로 사용될 수 있다. $\mathrm{Zhu}$ 연구팀은 탄소 지지체에 담지 된 $\mathrm{Co}_{3} \mathrm{O}_{4}$ 광촉매를 이용하여 물 산화 반응과 산소 환원 반응이 결 합된 시스템을 설계하였고, 이 시스템의 양 반응 모두를 통해 과산화수소를 생산하였다. ${ }^{62)}$ 또한 $\mathrm{CO}_{3} \mathrm{O}_{4}$ 에 산소 결 핍을 도입함으로써 밴드 갭의 감소, 전하 운반체 밀도의 증가, 효율적인 전자-정공 쌍의 분리 등의 효과를 통해 광촉매 성능이 향상되었으며(Fig. 3 (a)), 탄소 지지체는 산소 환원 반응의 활성 부위를 제공하였다. 이 시스템에 $420 \mathrm{~nm}$ 이상 파장의 가시광선을 조사할 때 Fig. 3 (b) 와 같이 $3.78 \mathrm{mmol} \mathrm{g}_{\mathrm{cat}}^{-1} \mathrm{~h}^{-1}$ 의 과산화수소 생산 속도 및 $0.4 \%$ 의 태양 에너지-물질 전환율을 달성하였으며, 720 시간 이상 안정적으로 구동하는 것을 확인하였다. $\mathrm{CaO}$ 연구팀 또한 산화 반응과 환원 반응 모두에서 과산 화수소를 생산하는 시스템을 설계하였다(Fig. 3 (c)). ${ }^{63)}$ 다공성 $\mathrm{g}-\mathrm{C}_{3} \mathrm{~N}_{4}$ 에 인을 도핑 함으로써 밴드 갭이 감소하 여 가시광선 영역에서의 흡수율이 증가하였고, 도핑 된 


\section{특 집 ㅁㅍ 임성제, 김광희, 김성순, 박종혁}

인이 산소의 흡착 부위로 작용해 과산화수소 발생 반응 을 촉진시켰다. 연구팀은 이 광촉매를 이용한 시스템에 가시광선을 조사하여 별도의 조촉매와 스캐빈저 없이 $1,968 \mu \mathrm{mol} \mathrm{g}_{\mathrm{cat}}{ }^{-1} \mathrm{~h}^{-1}$ 의 과산화수소 생산 속도를 달성하 였다(Fig. $3(\mathrm{~d}),(\mathrm{e}))$.

산소 환원 반응을 통한 과산화수소 생산 효율을 향상 시키기 위해서는 경쟁 반응인 수소 발생 반응 및 반응을 통해 생산된 과산화수소가 정공에 의해 물과 산소로 분 해되는 불균화 반응을 억제해야 한다. 이를 위해 $\mathrm{PEC}$ 시스템에 산화전극과 환원전극을 물리적으로 분리할 수 있는 챔버를 이용하여 과산화수소와 정공의 결합을 억 제하는 연구가 진행되었다. Mase 연구팀은 나피온 막을 챔버 분리막으로 사용한 시스템을 통해 과산화수소를 생산하였는데, $\mathrm{Co}^{\mathrm{II}}(\mathrm{Ch})$ 조촉매를 담지한 탄소 종이를 환원전극으로, $\mathrm{WO}_{3}$ 또는 $\mathrm{BiVO}_{4}$ 를 광산화전극으로 사용 하였다. ${ }^{64-66)}$ 전체 반응의 반응 속도는 $\left[\mathrm{Co}{ }^{\mathrm{III}}(\mathrm{ChH})\right]^{2+}$ 이 환원되어 $\mathrm{Co}(\mathrm{Ch})$ 이 형성되는 반응의 속도에 의해 결정 된다. 이 때, 전해질에 $\mathrm{HClO}_{4}$ 를 첨가하여 이 반응의 환 원 전위가 상승하였고 전체 반응 속도가 향상되었다. 그 결과 이 시스템은 $6.6 \%$ 의 태양 에너지-물질 전환율을 달성하였다.

\section{4. 산화 반응 기반 고부가가치 물질 생산 시스템}

\section{1 산화제 생산}

물 분해 반응을 기반으로 한 인공 광합성 시스템은 높 은 가치의 수소를 생산해내지만 상대반응으로 경제적 가치가 적은 산소를 생산하기 때문에 전체 시스템의 경 제적 한계점이 존재한다. 따라서 이러한 한계를 넘어서 기 위한 전략으로서 산소 발생 반응을 대신하여 고부가 가치 물질을 생산할 수 있는 산화 반응을 도입하는 연구 들이 진행되고 있다. 그중 산화제 생성 반응은 산화제의 경제적 가치가 높고 광산화전극에 사용되는 대부분의 반도체 소재가 $\mathrm{S}_{2} \mathrm{O}_{8}{ }^{2-}, \mathrm{ClO}^{-}, \mathrm{Ce}^{4+}$ 와 같은 산화제를 생 산하기에 충분히 낮은 가전자대를 가지기 때문에 산소 발생 반응을 대체하여 전체 시스템의 경제적 가치를 높 일 수 있다.
1987년 Desilvestro와 Grätzel은 EC 및 PEC 시스템 을 통한 $\mathrm{Cl}^{-}, \mathrm{Br}^{-}, \mathrm{HSO}_{4}^{-}, \mathrm{Fe}^{2+}, \mathrm{Ce}^{3+}$ 의 산화 반응에 대 해 연구하였다. ${ }^{67)}$ 연구팀은 전해질 내에 위와 같은 이온 들이 존재할 때 $\mathrm{SO}_{4}{ }^{2-}, \mathrm{ClO}_{4}{ }^{-}$용액에 비해 급격한 광전 류 변화가 발생하고, 그 결과 $\mathrm{Cl}^{-}, \mathrm{Br}^{-}, \mathrm{HSO}_{4}{ }^{-}, \mathrm{Fe}^{2+}$, $\mathrm{Ce}^{3+}$ 이온이 각각 $\mathrm{Cl}_{2}, \mathrm{Br}_{2}, \mathrm{~S}_{2} \mathrm{O}_{8}^{2-}, \mathrm{Fe}^{3+}, \mathrm{Ce}^{4+}$ 로 산화되 는 것을 발견하였다. 이러한 연구를 바탕으로 인공 광합 성 기술을 이용한 산화제 생산에 대해 다양한 연구가 진 행되었다. Nakajima 연구팀은 $\mathrm{WO}_{3}$ 나노스펀지 구조 의 광산화전극과 $1.0 \mathrm{M} \mathrm{H}_{2} \mathrm{SO}_{4}$ 전해질을 이용하여 수 소와 $\mathrm{S}_{2} \mathrm{O}_{8}{ }^{2-}$ 을 생산하는 시스템을 설계하였다. ${ }^{68)}$ 내부 적으로 연결되어 있는 $\mathrm{WO}_{3}$ 나노스펀지 구조로 인해 전 하 이동이 활발하게 발생하여 $3.04 \mathrm{~mA} \mathrm{~cm}{ }^{-2}$ 의 높은 광 전류밀도를 나타냈다(Fig. 4 (a)). 또한 수소와 $\mathrm{S}_{2} \mathrm{O}_{8}{ }^{2-}$ 에 대해 100\%에 가까운 패러데이 효율 및 $410 \mathrm{~nm}$ 파 장에서 $95.4 \%$ 의 $\mathrm{APCE}$ (absorbed photon to current efficiency)를 달성하였다. Ahn 연구팀은 메조 기공 구 조의 $\mathrm{WO}_{3}$ 에 나노플레이크 구조의 $\mathrm{WO}_{3}$ 를 성장시킨 광 산화전극을 이용한 $\mathrm{S}_{2} \mathrm{O}_{8}{ }^{2-}$ 생산 시스템을 설계하였다. ${ }^{69)}$ 나노플레이크 구조의 $\mathrm{WO}_{3}$ 와 $\mathrm{FTO}$ 간의 계면층이 전자정공 쌍의 재결합을 억제함으로써 효율적인 $\mathrm{S}_{2} \mathrm{O}_{8}{ }^{2-}$ 생산 이 가능하였고, $\mathrm{S}_{2} \mathrm{O}_{8}^{2-}$ 생성 반응에 대해 $95 \%$, 수소 발 생 반응에 대해 $100 \%$ 의 패러데이 효율 및 $2.6 \mathrm{~mA} \mathrm{~cm}{ }^{-2}$ 의 광전류밀도를 달성하였다.

$\mathrm{Cl}_{2}, \mathrm{HClO}, \mathrm{ClO}^{-}$와 같은 활성 염소종은 유기물 합 성, 폐수 처리, 소독 등 다양한 용도로 사용되는 산화제 이다. 염소는 해수에 $18.98 \mathrm{~g} \mathrm{~mL}^{-1}$ 의 풍부한 농도로 존 재하지만 이온화되어 있어 바로 산화제로 사용할 수 없 기 때문에 산화 반응을 통해 이를 $\mathrm{Cl}_{2}, \mathrm{HClO}, \mathrm{ClO}^{-}$등 의 사용 가능한 형태로 전환하는 것이 중요하다. 2011 년 $\mathrm{Luo}$ 연구팀은 $\mathrm{RhO}_{2}$ 가 도입된 $\mathrm{BiVO}_{4}$ 광산화전극을 해수 PEC 시스템에 이용하여 수소 발생 반응과 염소 산 화 반응을 결합하였다. ${ }^{70)}$ 시스템 구동시 광산화전극에서 기체 거품이 발생하지 않는 것을 확인하였고, 이를 통해 광전류가 산소 발생 반응이 아닌 물에 대한 용해도가 높 은 염소의 생성 반응에 의해 발생하였다는 것을 확인하 였다. Iguchi 연구팀은 $\mathrm{BiVO}_{4} / \mathrm{WO}_{3}$ 광산화전극을 이용 

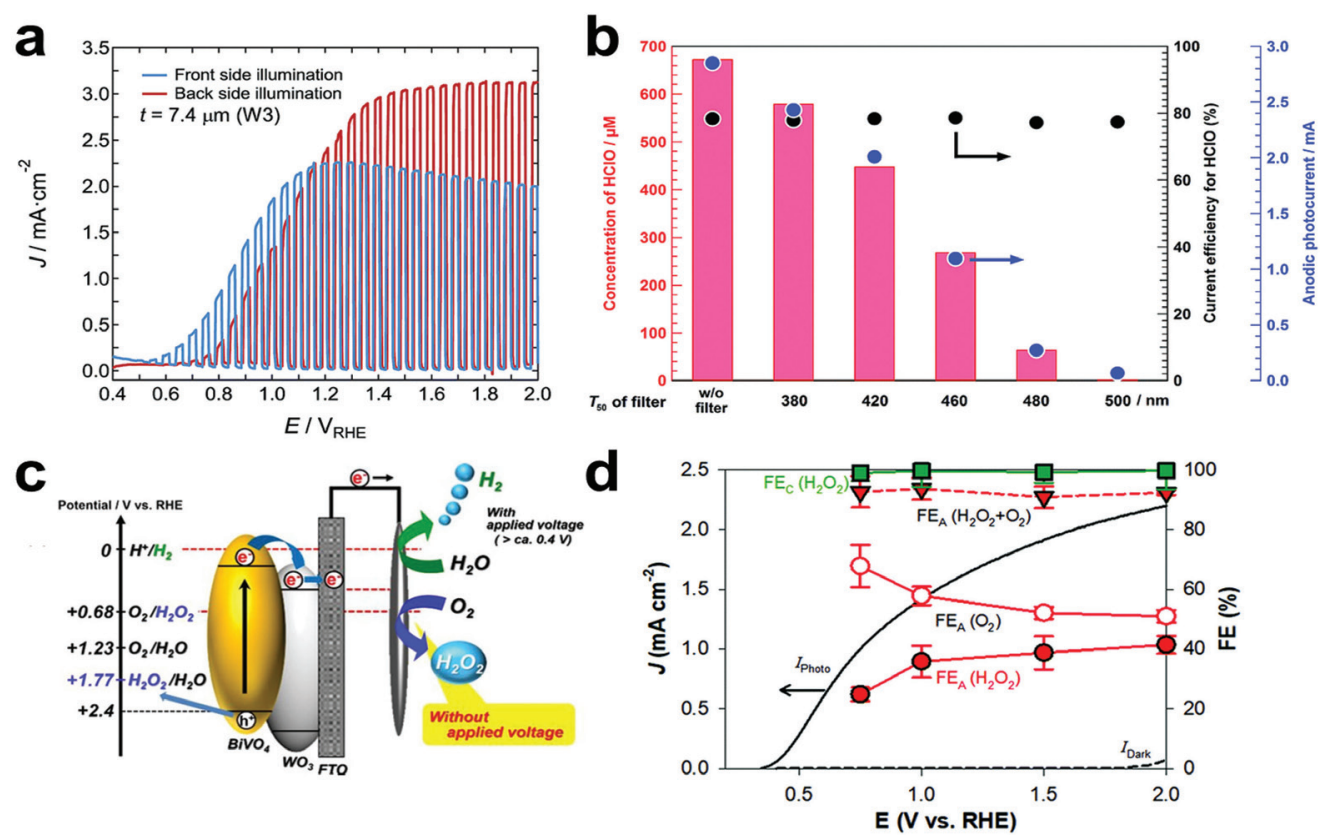

Fig. 4. a) $\mathrm{J}-\mathrm{V}$ curve of $\mathrm{WO}_{3}$ photocathode of front and back illumination. Reproduced with permission. ${ }^{68)}$ Copyright 2016, The Royal Society of Chemistry. b) The concentration of $\mathrm{HClO}$, current efficiency for $\mathrm{HClO}$ and anodic photocurrent according to various light filters. Reproduced with permission. ${ }^{71)}$ Copyright 2018, The Royal Society of Chemistry. c) Diagram of dual $\mathrm{H}_{2} \mathrm{O}_{2}$ production system. Reproduced with permission. ${ }^{7)}$ Copyright 2017, Wiley-VCH Verlag GmbH \& Co. KGaA, Weinheim. d) $\mathrm{J}-\mathrm{V}$ curve and faradaic efficiency of $\mathrm{Mo}-\mathrm{BiVO}_{4}$ and $\mathrm{AQ}-\mathrm{CNT} \mathrm{H}_{2} \mathrm{O}_{2}$ production system. Reproduced with permission. ${ }^{78)}$ Copyright 2020, The Royal Society of Chemistry.

해 산화제로 사용되는 $\mathrm{HClO}$ 와 수소를 생산하는 시스템 을 설계하였다. ${ }^{71)}$ 전해질의 $\mathrm{NaCl}$ 의 농도가 증가함에 따 라 시스템의 광전류밀도가 비례하여 증가하였으며, 염 화 이온 산화 반응에 대해 $81.4 \%$ 의 패러데이 효율을 달 성하였다(Fig. 4 (b)). 또한, 2000 초 간 시스템 구동에 서 $600 \mu \mathrm{M}$ 의 $\mathrm{HClO}$ 가 생성되는 것을 확인하였다.

산소 환원 반응을 통해 생산할 수 있는 과산화수소는 물 산화 반응을 통해서도 생산이 가능한 대표적인 산화 제이다. 이 때 물 산화를 통한 과산화수소의 생산은 경 제적 가치를 가지는 수소 발생 반응과 결합이 가능하기 때문에 전체 시스템의 경제적 가치를 높이는데 더 유리 하다고 할 수 있다. 과산화수소의 효율적인 생산을 위해 서는 경쟁 반응인 산소 발생 반응을 억제함으로써 반응 의 선택도를 높이는 것이 중요하다. ${ }^{72)} \mathrm{Zhu}$ 연구팀은 타 이타늄 실리칼라이트(TS-1)에 의해 안정된 나노점 형태 의 $\mathrm{CoO}$ 광촉매를 이용하여 물을 수소와 과산화수소로
분해하였다. ${ }^{73)} \mathrm{TS}-1$ 에 골고루 분산된 $\mathrm{CoO}$ 가 많은 활성 부위를 제공하며 높은 안정성, 표면적, 과산화수소 흡착 능력을 가진 TS-1이 과산화수소로부터 $\mathrm{CoO}$ 를 보호해 생성된 과산화수소의 분해를 억제하였다. 이러한 두 물 질의 결합을 통해 연구팀은 $1,460 \mu \mathrm{mol} \mathrm{g} \mathrm{cat}^{-1} \mathrm{~h}^{-1}$ 의 과 산화수소 생산 속도와 $1,390 \mu \mathrm{mol} \mathrm{g} \mathrm{gat}^{-1} \mathrm{~h}^{-1}$ 의 수소 생 산 속도를 얻을 수 있었다.

산소 발생 반응 억제를 통해 과산화수소 생산 속도의 향상이 가능하지만 산소 발생 반응만을 선택적으로 억 제하는 조촉매는 아직까지 보고된 바가 없다. 또한, 산 소 발생 반응의 에너지 장벽이 다른 반응들에 비해 낮기 때문에 다른 반응을 선택적으로 활성화하기 위해 산소 발생 반응을 억제하는 것은 어렵다고 여겨진다. 이러한 한계점을 극복하기 위해 $\mathrm{HCO}_{3}{ }^{-}$를 포함한 전해질을 이 용하여 물 산화를 통한 과산화수소 생성을 효과적으로 촉진시키는 전략에 대한 연구가 진행되었다. ${ }^{74-76)} \mathrm{Fuku}$ 


\section{특 집 ㅁㅃ 임성제, 김광희, 김성순, 박종혁}

연구팀은 $\mathrm{WO}_{3} / \mathrm{BiVO}_{4}$ 광산화전극과 $\mathrm{Au}$ 환원전극을 결 합하여 추가 전압 없이 양 전극 모두에서 과산화수소를 생산하였다(Fig. 4 (c)). 이 시스템은 전해질을 분리하기 위한 분리막이 사용되지 않았으며, $2.0 \mathrm{M} \mathrm{KHCO}_{3}$ 전해 질을 사용할 때 산화 반응에 대해 $50 \%$, 환원 반응에 대 해 $90 \%$ 의 패러데이 효율을 달성하였다. ${ }^{77)} \mathrm{Jeon}$ 연구팀 은 인산염 처리된 $\mathrm{BiVO}_{4}$ 를 광산화전극으로 사용하고, 안트라퀴논이 첨가된 탄소 나노튜브(AQ-CNT)를 환원 전극으로 사용하여 외부 전압 없이 양 전극에서 모두 과 산화수소를 생산하는 시스템을 설계하였다. ${ }^{78)} \mathrm{Mo}$ 도핑 을 통해 $\mathrm{BiVO}_{4}$ 의 $\mathrm{V}^{5+}$ 이 $\mathrm{Mo}^{6+}$ 으로 대체됨으로써 전하 운 반체 밀도가 증가하였고 이로 인해 광산화전극의 광전 류가 증가하였다. 또, $\mathrm{Mo}$ 도핑 된 $\mathrm{BiVO}_{4}$ 를 인산염 처 리함으로써 과산화수소가 광산화전극에 흡착되는 것을 억제하였고, 이로 인해 광산화전극에서 생성되는 정공 에 의해 과산화수소가 분해되는 것을 최소화하였다. 환 원전극의 안트라퀴논은 앞서 언급한 산화 - 환원 반응의 매개체 역할을 통해 전하 전달을 촉진시켰다. 이러한 시 스템을 통해 연구팀은 외부 전압 없이 산화 반응에 대해 40 50\%, 환원 반응에 대해 100\%의 패러데이 효율을 달성하였다(Fig. 4 (d)).

\section{2 유기 합성}

유기 합성은 화학 산업의 가장 대표적이고 역사가 오 래된 분야이다. 대부분의 유기 합성 반응은 고온 및 고 압의 환경에서 이루어지기 때문에 상온, 상압 조건에서 낮은 에너지 소모로 물질 합성이 가능한 인공 광합성 시 스템이 큰 관심을 받고 있다. 인공 광합성 시스템에 사 용되는 대부분의 반도체 소재는 높은 안정성으로 재사 용이 가능하여 설계 및 관리 비용을 절약할 수 있고, 광 전극의 가전자대와 전도대에서 생성되는 높은 에너지를 가진 전자와 정공을 통해 다양한 종류의 유기물을 합성 하는 것이 가능하다.

Xie 연구팀은 $\mathrm{MoS}_{2}$ 가 도입된 $\mathrm{CdS}$ 광촉매를 이용하 여 에틸렌 글라이콜을 생산하였다. ${ }^{79)}$ 연구팀은 메탄올 이 포함된 전해질에서 다양한 $\mathrm{PC}$ 반도체 소재의 유기 합성 반응 촉매 성능을 확인하였고, 대부분의 소재가 공
통적으로 수소와 폼알데하이드를 주 생성물로 생산하 는 것을 확인하였다. 이로부터 연구팀은 대부분의 반도 체 소재가 $\mathrm{O}-\mathrm{H}$ 결합을 쉽게 활성화함에 반해 $\mathrm{C}-\mathrm{H}$ 결 합은 활성화하기 어렵다는 것을 발견하였다. 반면, $\mathrm{CdS}$ 는 $\mathrm{C}-\mathrm{H}$ 결합의 활성화에 의해 일어나는 에틸렌 글라 이콜 생성 반응에 대해 높은 선택도를 보였고, 더불어 $\mathrm{MoS}_{2}$ 가 CdS 나노로드 표면에 도입되었을 때 촉매 반응 성이 눈에 띄게 향상되어 $90 \%$ 의 에틸렌 글라이콜 생성 선택도와 각각 $11 \mathrm{mmol} \mathrm{g}_{\text {cat }}{ }^{-1} \mathrm{~h}^{-1}, 12 \mathrm{mmol} \mathrm{g}_{\mathrm{cat}}{ }^{-1} \mathrm{~h}^{-1}$ 의 에틸렌 글라이콜, 수소 생산 속도를 달성하였다(Fig. 5 (a)). 이후, Zhang 연구팀은 $\mathrm{C}-\mathrm{H}$ 결합의 활성화를 이 용하여 메탄올, 에탄올을 각각 에틸렌 글라이콜, $2,3-$ 뷰타다이엔으로 전환하는 시스템을 설계하였다. ${ }^{80)}$ 연구 팀은 광촉매로 사용된 $\mathrm{Zn}_{2} \mathrm{In}_{2} \mathrm{~S}_{5}$ 의 $\mathrm{Zn}$ 과 $\mathrm{In}$ 의 구성 비율 이 에틸렌 글라이콜 생성 반응과 강한 연관성이 있음을 확인하였다. 그리고 $\mathrm{CoP}$ 조촉매를 도입함으로써 반응 성능이 눈에 띄게 향상되었으며, 에틸렌 글라이콜 생성 반응에 대한 $90 \%$ 의 선택도와 $18.9 \mathrm{mmol} \mathrm{g}_{\mathrm{cat}}{ }^{-1} \mathrm{~h}^{-1}$ 의 생 산 속도를 달성하였다.

방향족 화합물 또한 인공 광합성을 통해 생산할 수 있 는 고부가가치 물질 중 하나이다. 방향족 화합물은 무극 성이고 매우 안정한 고리 구조의 결합 형태를 가지고 있 어 고리 구조의 결합을 파괴하는 것이 매우 어렵기 때문 에, 대부분의 방향족 화합물 생산 연구는 고리에 연결된 작용기를 교체, 수정하는 방향으로 진행되고 있다. Hao 연구팀은 벤질알코올을 산화시켜 벤잘데하이드를 생산 하는 PC 시스템을 설계하였다. ${ }^{81)} \mathrm{ZnS}$ 나노로드에 $\mathrm{Ni}_{\mathrm{x}} \mathrm{S}_{\mathrm{y}}$ 을 첨가함으로써 수소 발생 반응과 벤잘데하이드 생성 반응 모두에 대해 광촉매 성능이 향상되었고, 특히 벤잘 데하이드 생성 반응에 대해 $49.3 \%$ 의 전환율 및 $80.4 \%$ 의 선택도를 달성하였다. Luo 연구팀은 데옥시벤조인과 수소를 생산하는 적층형 산화 · 환원 시스템을 설계하였 다. ${ }^{82)} \mathrm{ZnIn}$ 황화물에서 생성된 정공에 의해 벤질알코올 이 산화되어 하이드로벤조인이 생성되고, 그 후 하이드 로벤조인의 탈수반응에 의해 데옥시벤조인이 생산되었 다. 또, $\mathrm{ZnIn}$ 황화물에서 $\mathrm{Zn}$ 의 구성 비율이 증가함에 따라 데옥시벤조인의 생산 속도가 증가하고 벤잘데하이 

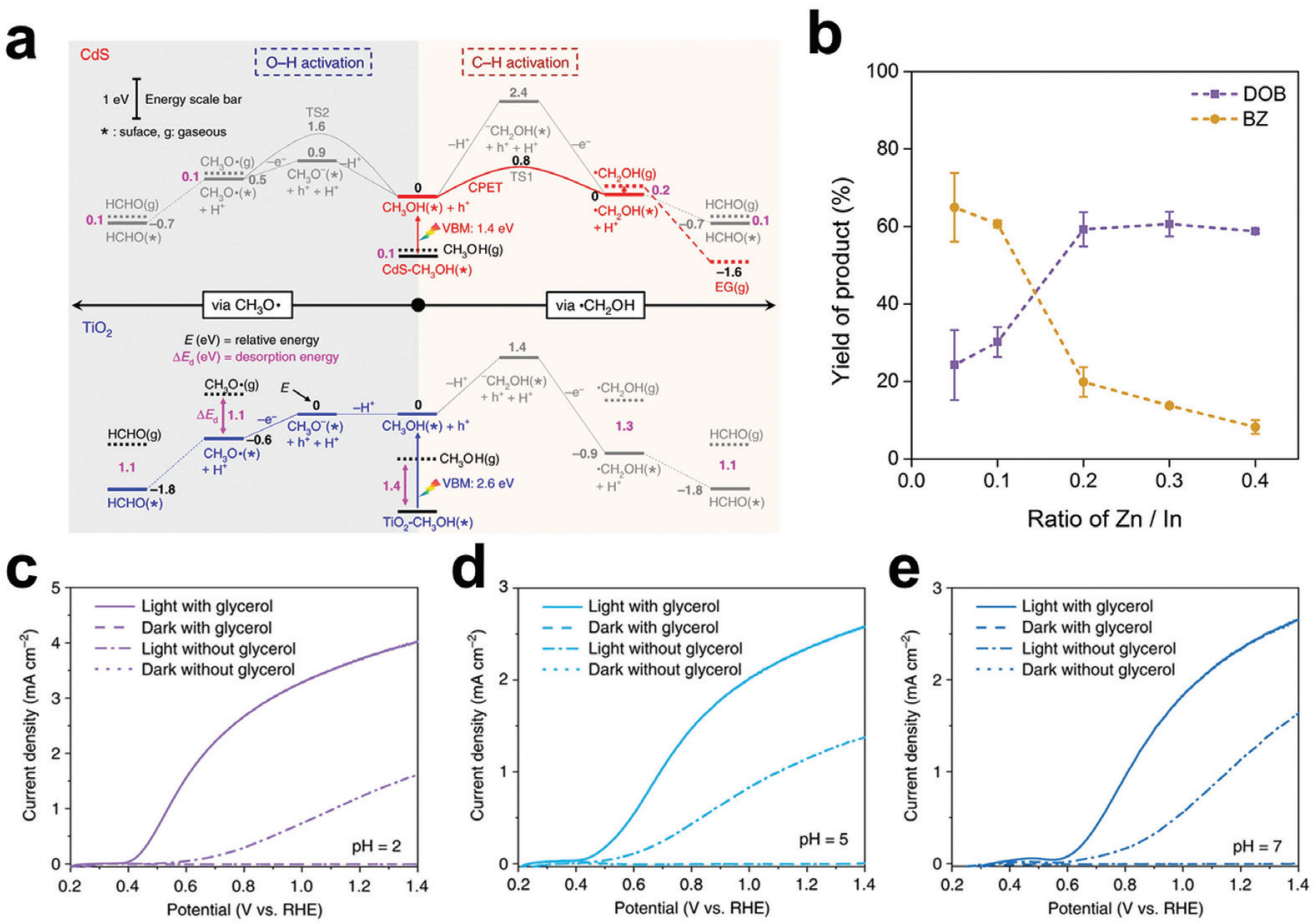

Fig. 5. a) Reaction energy profiles of methanol conversion of $\mathrm{O}-\mathrm{H}$ and $\mathrm{C}-\mathrm{H}$ activation. Reproduced with permission. ${ }^{79)}$ Copyright 2018, Springer Nature. b) Yields of deoxybenzoin (DOB) and benzaldehyde (BZ) according to Zn/In ratio. Reproduced with permission. ${ }^{82}$ Copyright 2020, American Chemical Society. J-V curves of glycerol oxidation of $\mathrm{BiVO}_{4}$ photoanode when c) $\mathrm{pH}=2, \mathrm{~d}) \mathrm{pH}=5$, and e) $\mathrm{pH}=7$. c-e) Reproduced with permission. ${ }^{83)}$ Copyright 2019, Springer Nature.

드의 생산 속도가 감소하여 이를 통해 생성물의 선택도 가 증가하였다(Fig. 5 (b)).

글리세롤은 3 개의 수산화기를 가지는 C3 탄화수소이 자 바이오디젤 제조 과정에서 생산되는 부산물이다. 최 근 바이오디젤 제조 산업이 성장함에 따라 글리세롤의 생산량이 연 수요를 초과하기에 이르렀기 때문에, 글리 세롤을 다른 고부가가치 물질로 전환하는 반응에 대한 연구를 통해 공정비용의 감소 및 시스템의 경제적 가치 를 높일 수 있다. 특히 인공 광합성 시스템의 경우 수계 전해질을 사용하는데, 글리세롤은 분자 구조상 대부분 의 무극성 탄화수소에 비해 물에 대한 용해성이 높기 때 문에 인공 광합성 시스템에 이용하기에 적합하다는 장 점을 가진다. $\mathrm{Liu}$ 연구팀은 전해질의 $\mathrm{pH}$ 및 인가전압에 따른 글리세롤 산화 반응 시스템에 대해 연구하였다. ${ }^{83)}$ 기존 물 분해 반응에 널리 사용되는 $\mathrm{BiVO}_{4}$ 를 광산화전 극으로 사용하여 $\mathrm{pH} 2,1.2 \mathrm{~V}$ vs RHE의 환경에서 3.7
$\mathrm{mA} \mathrm{cm}$ 의 광전류밀도와 다이하이드록시아세톤(DHA) 생성 반응에 대해 $51 \%$ 의 선택도 및 $200 \mathrm{mmol} \mathrm{h} \mathrm{h}^{-1} \mathrm{~m}^{-2}$ 의 생산 속도를 달성하였다(Fig. 5 (c)-(e)). $\mathrm{BiVO}_{4}$ 의 [112] 표면에서 광 생성된 정공에 의해 글리세롤이 산화 된 후 수화 반응, 탈수 반응을 거쳐 가장 안정한 3 차 라 디칼의 형태를 갖게 되고, 이를 통해 선택적인 DHA 생 산이 가능하였다.

\section{5. 결론 및 전망}

최근의 인공 광합성 연구는 산화 반응과 환원 반응 을 통해 양쪽 반응 모두에서 고부가가치 물질을 생산하 는 방향으로 진행되고 있다. 기존 물 분해 반응에서 이 미 널리 사용되어온 $\mathrm{TiO}_{2}, \mathrm{WO}_{3}, \mathrm{BiVO}_{4}, \mathrm{CdS}$ 등의 인 공 광합성 반도체 소재들과 이산화탄소 환원 반응, 과산 화수소 생성 반응, 산화제 생성 반응, 유기 합성 반응 등 
의 다양한 종류의 산화, 환원 반응들을 적용한 인공 광 합성 시스템들이 연구되었으며, 이러한 연구를 통해 인 공 광합성의 상용화를 앞당길 수 있을 것으로 예상된다. 하지만 아직 인공 광합성의 상용화를 위해서는 높은 효 율, 높은 선택도, 안정성 등 여러 과제들을 해결해야 한 다. 예를 들어, 수용액 상태에서는 수소 발생 반응과 산 소 발생 반응이 가장 일어나기 쉽기 때문에 이러한 경쟁 반응의 억제를 위해 조촉매, 반응 단계의 조절 등이 필 요하며 또한 다양한 산화, 환원 반응의 효율을 위한 인 공 광합성 반도체 소재 및 반응 메커니즘에 대한 연구들 이 지속적으로 진행될 필요가 있다.

추가적으로 인공 광합성 시스템을 통한 고부가가치 물질 생산에 있어 이용 가능한 수준의 순도로 생성물을 분리해내는 것 또한 중요하다. 대부분의 인공 광합성 시 스템은 액체 전해질 환경에서 진행되므로 액체 생성물 에 대해서는 분리 공정이 추가적으로 필요하게 된다. 가 장 대표적인 분리 공정인 증류 공정은 두 물질의 구성 비율의 차이가 적은 상황에서 사용되는데 인공 광합성 시스템에서 일반적으로 생산된 물질의 농도가 낮으므로 증류 공정을 적용하기에 적합하지 않다. 또한 $\mathrm{C} 1, \mathrm{C} 2$ 탄 화수소와 같이 분리해야 하는 물질들이 물과 공비혼합 물을 형성하거나, 과산화수소와 같이 물질의 안정성이 낮은 경우 증류 공정 통한 생성물의 분리는 불가능에 가 깝다. 이 때문에 분리막을 이용한 선택적 투과, 액체 유 기물의 분리에 적합한 염 보조 액체-액체 추출법 등의 다른 분리법이 인공 광합성 시스템에 적용될 수 있다. 인공 광합성 기술의 소재 및 메커니즘 연구와 분리 공정 의 활발한 연구를 통해 인공 광합성 기술 기반 고부가가 치 물질 생산 시스템의 상용화를 달성할 수 있을 것으로 기대된다.

\section{REFERENCES}

1. N. S. Lewis and D. G. Nocera, "Powering the Planet: Chemical Challenges in Solar Energy Utilization," Proc. Natl. Acad. Sci. U.S.A., 103 [43] 15729-35 (2006).

2. N. S. Lewis, "Research Opportunities to Advance Solar
Energy Utilization," Science, 351 [6271] aad1920 (2016).

3. A. Kudo and Y. Miseki, "Heterogeneous Photocatalyst Materials for Water Splitting," Chem. Soc. Rev., 38 [1] 253-78 (2009).

4.F. E. Osterloh, "Inorganic Nanostructures for Photoelectrochemical and Photocatalytic Water Splitting," Chem. Soc. Rev., 42 [6] 2294-320 (2013).

5. K. Maeda and K. Domen, "Photocatalytic Water Splitting: Recent Progress and Future Challenges," $J$. Phys. Chem. Lett., 1 [18] 2655-61 (2010).

6. M. G. Lee, J. S. Park and H. W. Jang, "SolutionProcessed Metal Oxide Thin Film Nanostructures for Water Splitting Photoelectrodes: A Review," J. Korean Ceram. Soc., 55 [3] 185-202 (2018).

7. Z. Chen, T. F. Jaramillo, T. G. Deutsch, A. KleimanShwarsctein, A. J. Forman, N. Gaillard, R. Garland, K. Takanabe, C. Heske, M. Sunkara, E. W. McFarland, K. Domen, E. L. Miller, J. A. Turner and H. N. Dinh, "Accelerating Materials Development for Photoelectrochemical Hydrogen Production: Standards for Methods, Definitions, and Reporting Protocols," $J$. Mater. Res., 25 [1] 3-16 (2010).

8. K. Zhang, M. Ma, P. Li, D. H. Wang and J. H. Park, "Water Splitting Progress in Tandem Devices: Moving Photolysis beyond Electrolysis," Adv. Energy Mater, 6 [15] 1600602 (2016).

9. A. Fujishima and K. Honda, "Electrochemical Photolysis of Water at a Semiconductor Electrode," Nature, 238 [5358] 37-8 (1972).

10. X. Chen, S. Shen, L. Guo and S. S. Mao, "Semiconductor-Based Photocatalytic Hydrogen Generation," Chem. Rev., 110 [11] 6503-70 (2010).

11. J. Schneider, M. Matsuoka, M. Takeuchi, J. Zhang, Y. Horiuchi, M. Anpo and D. W. Bahnemann, "Understanding $\mathrm{TiO}_{2}$ Photocatalysis: Mechanisms and Materials," Chem. Rev., 114 [19] 9919-86 (2014).

12. H. L. Tan, R. Amal and Y. H. Ng, "Alternative Strategies in Improving the Photocatalytic and Photoelectrochemical Activities of Visible LightDriven $\mathrm{BiVO}_{4}$ : A Review," J. Mater. Chem. A, 5 [32] 16498-521 (2017).

13. C. M. Suarez, S. Hernández and N. Russo, " $\mathrm{BiVO}_{4}$ as a Photocatalyst for Solar Fuels Production through Water Splitting: A Short Review," Appl. Catal. A, $\mathbf{5 0 4}$ 
158-70 (2015).

14. S. Cao, J. Low, J. Yu and M. Jaroniec, "Polymeric Photocatalysts Based on Graphitic Carbon Nitride," Adv. Mater, 27 [13] 2150-76 (2015).

15. Z. Zhao, Y. Sun and F. Dong, "Graphitic Carbon Nitride Based Nanocomposites: A Review," Nanoscale, 7 [1] 15-37 (2015).

16. L. Wu, L. Tsui and G. Zangari, "Photoelectrochemical Stability of Electrodeposited $\mathrm{Cu}_{2} \mathrm{O}$ Films," J. Phys. Chem. C, 114 [26] 11551-56 (2010).

17. L. Cheng, Q. Xiang, Y. Liao and H. Zhang, "CdSBased Photocatalyst," Energy Environ. Sci., 11 [6] 1362-91 (2018).

18. Y. J. Yuan, D. Chen, Z. T. Yu and Z. G. Zou, "Cadmium Sulfide-Based Nanomaterials for Photocatalyic Hydrogen Production," J. Mater. Chem. $A, 6$ [25] 11606-30 (2018).

19. Y. Wu, P. Lazic, G. Hautier, K. Persson and G. Ceder, "First Principles High Throughput Screening of Oxynitrides for Water-Splitting Photocatalysts," Energy Environ. Sci., 6 [1] 157-68 (2013).

20. C. Pan, T. Takata, M. Nakabayashi, T. Matsumoto, N. Shibata, Y. Ikuhara and K. Domen, "A Complex Perovskite-Type Oxynitride: The First Photocatalysts for Water Splitting Operable at up to $600 \mathrm{~nm}$," Angew. Chem. Int. Ed., 54 [10] 2955-9 (2015).

21. Q. Wang, M. Nakabayashi, T. Hisatomi, S. Sun, S. Akiyama, Z. Wang, Z. Pan, X. Xiao, T. Watanabe, T. Yamada, N. Shibata, T. Takata and K. Domen, "Oxysulfide Photocatalyst for Visible-Light-Driven Overall Water Splitting," Nat. Mater., 18 [8] 827-32 (2019).

22. S. J. A. Moniz, S. A. Shevlin, D. J. Martin, Z. X. Guo and J. Tang, "Visible-Light Driven Heterojunction photocatalysts for Water Splitting - A Critical Review," Energy Environ. Sci., 8 [3] $731-59$ (2015).

23. J. Low, J. Yu, M. Jaroniec, S. Wageh and A. A. AlGhamdi, "Heterojunction Photocatalysts," Adv. Mater, 29 [20] 1601694 (2017).

24. T. Takata and K. Domen, "Defect Engineering of Photocatalysts by Doping of Aliovalent Metal Cations for Efficient Water Splitting," J. Phys. Chem. C, 113 [45] 19386-8 (2009).

25. J. H. Park, S. Kim and A. J. Bard, "Novel CarbonDoped $\mathrm{TiO}_{2}$ Nanotube Arrays With High Aspect Ratios for Efficient Solar Water Splitting," Nano letters, 6 [1] 24-8 (2006).

26. Y. Kuang, T. Yamada snd K. Domen, "Surface and Interface Engineering for Photoelectrochemical Water Oxidation," Joule, 1 [2] 290-305 (2017).

27. T. Su, Q. Shao, Z. Qin, Z. Guo and Z. Wu, "Role of Interfaces in Two-Dimensional Photocatalyst for Water Splitting," ACS Catal., 8 [3] 2253-76 (2018).

28. S. Bai, W. Jiang, Z. Li and Y. Xiong, "Surface and Interface Engineering in Photocatalysis," ChemNanoMat, 1 [4] 223-39 (2015).

29. J. Ran, J. Zhang, J. Yu, M. Jaroniec and S. Z. Qiao, "Earth-Abundant Cocatalysts for SemicundoctorBased Photocatalytic Water Splitting," Chem. Soc. Rev., 43 [22] 7787-812 (2014).

30. X. Chang, T. Wang, P. Yang, G. Zhang and J. Gong, "The Development of Cocatalysts for photoelectrochemical $\mathrm{CO}_{2}$ Reduction," Adv. Mater. 31 [31] 1804710 (2019).

31. F. Parrino, M. Bellardita, E. I. García-López, G. Marcì, V. Loddo and L. Palmisano, "Heterogeneous Photocatalysis for Selective Formation of High-ValueAdded Molecules: Some Chemical and Engineering Aspects," ACS Catal., 8 [12] 11191-225 (2018).

32. J. Liu, Y. Zou, B. Jin, K. Zhang and J. H. Park, "Hydrogen Peroxide Production from Solar Water Oxidation," ACS Energy Lett., 4 [12] 3018-27 (2019).

33. V. Kumaravel, J. Bartlett and S. C. Pillai, "Photoelectrochemical Conversion of Carbon Dioxide $\left(\mathrm{CO}_{2}\right)$ into Fuels and Value-Added Products," ACS Energy Lett., 5 [2] 486-519 (2020).

34. K. Sayama, "Production of High-Value-Added Chemicals on Oxide Semiconductor Photoanodes under Visible Light for Solar Chemical-Conversion Processes," ACS Energy Lett., 3 [5] 1093-101 (2018).

35. S. D. Tilley, "Recent Advances and Emerging Trends in Photo-Electrochemical Solar Energy Conversion," Adv. Energy Mater., 9 [2] 1802877 (2019).

36. L. M. Reid, T. Li, Y. Cao and C. P. Berlinguette, "Organic Chemistry at Anodes and Photoanodes," Sustain. Energy Fuels, 2 [9] 1905-27 (2018).

37. W. Tu, Y. Zhou and Z. Zou, "Investing the Role of Tunable Nitrogen Vacancies in Graphitic Carbon Nitride Nanosheets for Efficient Visible-Light-Driven $\mathrm{H}_{2}$ Evolution and $\mathrm{CO}_{2}$ Reduction," Adv. Mater, 5 [8] 7260-8 (2017).

38. X. Liu, S. Inagaki and J. Gong, "Heterogeneous 
Molecular Systems for Photocatalytic $\mathrm{CO}_{2}$ Reduction with Water Oxidation," Angew. Chem. Int. Ed., 55 [48] 14924-50 (2016).

39. S. Zeng, P. Kar, U. K. Thakur and K. Shankar, “A Review on Photocatalytic $\mathrm{CO}_{2}$ Reduction Using Perovskite Oxide Nanomaterials," Nanotechnology, 29 [5] 052001 (2018).

40. J. Ran, M. Jaroniec and S. Z. Qiao, "Metallic MoN Ultrathin Nanosheets Boosting High Performance Photocatalytic $\mathrm{H}_{2}$ Production," J. Mater. Chem. A, 6 [46] 23278-82 (2018).

41. K. Zhang, J. Liu, L. Wang, B. Jin, X. Yang, S. Zhang and J. H. Park, "Near-Complete Suppression of Oxygen Evolution for Photoelectrochemical $\mathrm{H}_{2} \mathrm{O}$ Oxidative $\mathrm{H}_{2} \mathrm{O}_{2}$ Synthesis," J. Am. Chem. Soc., 142 [19] 8641-8 (2020).

42. R. Beranek, "Selectivity of Chemical Conversion: Do Light-Driven Photoelectrocatalytic Processes Hold Special Promise?," Angew. Chem. Int. Ed., 58 [47] 16724-9 (2019)

43. X. Nie, W. Luo, M. J. Janik and A. Asthagiri, "Reaction Mechanisms of $\mathrm{CO}_{2}$ Electrochemical Reduction on $\mathrm{Cu}\left(\begin{array}{lll}1 & 1 & 1\end{array}\right)$ Determined with Density Functional Theory," J. Catal., 312 108-22 (2014).

44. A. Ali, M. R. D. Biswas, Y. Areerob, D. C. T. Nguyen and W. C. Oh, "Synthesis and Characterization of a Ternary Nanocomposite Based on CdSe Decorated Graphene- $\mathrm{TiO}_{2}$ and Its Application in the Quantitative Analysis of Alcohol with Reduction of $\mathrm{CO}_{2}, " J$. Korean Ceram. Soc., 55 [4] 381-91 (2018).

45. M. Halmann, "Photoelectrochemical Reduction of Aqueous Carbon Dioxide on P-Type Gallium Phosphide in Liquid Junction Solar Cells," Nature, 275 [5676] 115-6 (1978).

46. G. Yin, H. Abe, R. Kodiyath, S. Ueda, N. Srinivasan, A. Yamaguchi and M. Miyauchi, "Selective Electroor Photo-Reduction of Carbon Dioxide to Formic Acid Using a Cu-Zn Alloy Catalyst," J. Mater. Chem. A, 5 [24] 12113-9 (2017).

47. I. H. Tseng, W. C. Chang and J. C. S. Wu, "Photoreduction of $\mathrm{CO}_{2}$ Using Sol-Gel Derived Titania and Titania-Supported Copper Catalysts," Appl. Catal. B, 37 [1] 37-48 (2002).

48. J. Cheng, M. Zhang, G. Wu, X. Wang, J. Zhou and K. Cen, "Photoelectrocatalytic Reduction of $\mathrm{CO}_{2}$ into Chemicals Using Pt-Modified Reduced Graphene
Oxide Combined with Pt-Modified $\mathrm{TiO}_{2}$ Nanotubes," Environ. Sci. Technol., 48 [12] 7076-84 (2014).

49. M. Ou, W. Tu, S. Yin, W. Xing, S. Wu, H. Wang, S. Wan, Q. Zhong and R. Xu, "Amino-Assisted Anchoring of $\mathrm{CsPbBr}_{3}$ Perovskite Quantum Dots on Porous $\mathrm{g}-\mathrm{C}_{3} \mathrm{~N}_{4}$ for Enhanced Photocatalytic $\mathrm{CO}_{2}$ Reduction," Angew. Chem. Int. Ed., 130 [41] 1375862 (2018).

50. F. Ye, F. Wang, C. Meng, L. Bai, J. Li, P. Xing, B. Teng, L. Zhao and S. Bai, "Crystalline Phase Engineering on Cocatalysts: A Promising Approach to Enhancement on Photocatalytic Conversion of Carbon Dioxide to Fuels," Appl. Catal. B, 230 145-53 (2018).

51. X. Cai, J. Wang, R. Wang, A. Wang, S. Zhong, J. Chen and S. Bai, "Interface Engineering on Janus $\mathrm{Pd}-\mathrm{Au}$ Heterojunction Co-Catalysts for Selective Photocatalytic Reduction of $\mathrm{CO}_{2}$ to $\mathrm{CH}_{4}$," J. Mater. Chem. A, 7 [10] 5266-76 (2019).

52. Q. Lang, Y. Yang, Y. Zhu, W. Hu, W. Jiang, S. Zhong, P. Gong, B. Teng, L. Zhao and S. Bai, "High-Index Facet Engineering of $\mathrm{PtCu}$ Cocatalysts for Superior Photocatalytic Reduction of $\mathrm{CO}_{2}$ to $\mathrm{CH}_{4}$," J. Mater. Chem. A, 5 [14] 6686-94 (2017).

53. B. Pan, S. Luo, W. Su and X. Wang, "Photocatalytic $\mathrm{CO}_{2}$ Reduction with $\mathrm{H}_{2} \mathrm{O}$ over $\mathrm{LaPO}_{4}$ Nanorods Deposited with Pt Cocatalyst," Appl. Catal. B, 168 458-64 (2015).

54. W. N. Wang, W. J. An, B. Ramalingam, S. Mukherjee, D. M. Niedzwiedzki, S. Gangopadhyay and P. Biswas, "Size and Structure Matter: Enhanced $\mathrm{CO}_{2}$ Photoreduction Efficiency by Size-Resolved Ultrafine Pt Nanoparticles on $\mathrm{TiO}_{2}$ Single Crystals," J. Am. Chem. Soc., 134 [27] 11276-81 (2012).

55. Ş. Neaţu, J. A. M. Agulló, P. Concepción, H. Garcia, "Gold-Copper Nanoalloys Supported on $\mathrm{TiO}_{2}$ as Photocatalysts for $\mathrm{CO}_{2}$ Reduction by Water," J. Am. Chem. Soc., 136 [45] 15969-76 (2014).

56. Y. Jia, Y. Xu, R. Nie, F. Chen, Z. Zhu, J. Wang and H. Jing, "Artificial Photosynthesis of Methanol from Carbon Dioxide and Water via a Nile Red-Embedded $\mathrm{TiO}_{2}$ Photocathode," J. Mater. Chem. A, 5 [11] 5495 501 (2017).

57. J. Wang, B. Han, R. Nie, Y. Xu, X. Yu, Y. Dong, J. Wang and H. Jing, "Photoelectrocatalytic Reduction of $\mathrm{CO}_{2}$ to Chemicals via $\mathrm{ZnO} @$ Nickel Foam: 
Controlling C-C Coupling by Ligand or Morphology," Top. Catal., 61 [15-17] 1563-73 (2018).

58. L. Wang, Y. Jia, R. Nie, Y. Zhang, F. Chen, Z. Zhu, J. Wang and H. Jing, "Ni-Foam-Supported and Amine Functionalized $\mathrm{TiO}_{2}$ Photocathode Improved Photoelectrocatalytic Reduction of $\mathrm{CO}_{2}$ to Methanol," J. Catal., 349 1-7 (2017).

59. C. Li, T. Wang, B. Liu, M. Chen, A. Li, G. Zhang, M. Du, H. Wang, S. F. Liu and J. Gong, "Photoelectrochemical $\mathrm{CO}_{2}$ Reduction to Adjustable Syngas on Grain-Boundary-Mediated a-Si/ $\mathrm{TiO}_{2} / \mathrm{Au}$ Photocathodes with Low Onset Potentials,"Energy Environ. Sci., 12 [3] 923-8 (2019).

60. G. X. Dong, W. Zhang, Y. F. Mu, K. Su, M. Zhang and T. B. Lu, "A Halide Perovskite as a Catalyst to Simultaneously Achieve Effecient Photocatalytic $\mathrm{CO}_{2}$ Reduction and Methanol Oxidation," Chem. Commun., 56 [34] 4664-7 (2020).

61. Q. Guo, F. Liang, X. B. Li, Y. J. Gao, M. Y. Huang, Y. Wang, S. G. Xia, X. Y. Gao, Q. C. Gan, Z. S. Lin, C. H. Tung and L. Z. Wu, "Efficient and Selective $\mathrm{CO}_{2}$ Reduction Integrated with Organic Synthesis by Solar Energy," Chem, 5 [10] 2605-16 (2019).

62. C. Zhu, M. Zhu, Y. Sun, Y. Zhou, J. Gao, H. Huang, Y. Liu and Z. Kang, "Carbon-Supported Oxygen Vacancy-Rich $\mathrm{Co}_{3} \mathrm{O}_{4}$ for Robust Photocatalytic $\mathrm{H}_{2} \mathrm{O}_{2}$ Production via Coupled Water Oxidation and Oxygen Reduction Reaction," ACS Appl. Energy Mater., 2 [12] 8737-46 (2019).

63. J. Cao, H. Wang, Y. Zhao, Y. Liu, Q. Wu, H. Huang, M. Shao and Z. Kang, "Phosphorus-Doped Porous Carbon Nitride for Efficient Sole Production of Hydrogen Peroxide via Photocatalytic Water Splitting with a Two-Channel Pathway," J. Mater. Chem. A, 8 [7] 3701-7 (2020).

64. K. Mase, M. Yoneda, Y. Yamada and S. Fukuzumi, "Efficient Photocatalytic Production of Hydrogen Peroxide from Water and Dioxygen with Bismuth Vanadate and a Cobalt (II) Chlorin Complex," ACS Energy Lett., 1 [5] 913-9 (2016).

65. K. Mase, M. Yoneda, Y. Yamada and S. Fukuzumi, "Seawater Usable for Production and Consumption of Hydrogen Peroxide as a Solar Fuel," Nat. Commun., 7 [1] 1-7 (2016).

66. K. Mase, K. Ohkubo and S. Fukuzumi, "Efficient Two-Electron Reduction of Dioxygen to Hydrogen
Peroxide with One-Electron Reductants with a Small Overpotential Catalyzed by a Cobalt Chlorin Complex," J. Am. Chem. Soc., 135 [7] 2800-8 (2013).

67. J. Desilvestro and M. Grätzel, "Photoelectrochemistry of Polycrystalline $\mathrm{n}-\mathrm{WO}_{3}$ : Electrochemical Characterization and Photoassisted Oxidation Processes," J. Electroanal. Chem., 238 [1-2] 129-50 (1987).

68. T. Nakajima, A. Hagino, T. Nakamura, T. Tsuchiya and K. Sayama, " $\mathrm{WO}_{3}$ Nanosponge Photoanodes with High Applied Bias Photon-to-Current Efficiency for Solar Hydrogen and Peroxydisulfate Production," J. Mater. Chem. A, 4 [45] 17809-18 (2016).

69. S. H. Ahn, J. Zhao, J. H. Kim and X. Zheng, "Effect of Interfacial Blocking Layer Morphology on the Solar Peroxydisulfate Production of $\mathrm{WO}_{3}$ Nanoflakes," Electrochim. Acta, 244 184-191 (2017).

70. W. Luo, Z. Yang, Z. Li, J. Zhang, J. Liu, Z. Zhao, Z. Wang, S. Yan, T. Yu and Z. Zou, "Solar Hydrogen Generation from Seawater with a Modified $\mathrm{BiVO}_{4}$ Photoanode," Energy Environ. Sci., 4 [10] 4046-51 (2011).

71. S. Iguchi, Y. Miseki and K. Sayama, "Efficient Hypochlorous Acid ( $\mathrm{HClO}$ ) Production via Photoelectrochemical Solar Energy Conversioin Using a $\mathrm{BiVO}_{4}$-Based Photoanode," Sustain. Energy Fuels, 2 [1] 155-62 (2018).

72. S. Y. Park, H. Abroshan, X. Shi, H. S. Jung, S. Siahrostami and X. Zheng, "CaSnO${ }_{3}$ : An Electrocatalysts for Two-Electron Water Oxidation Reaction to Form $\mathrm{H}_{2} \mathrm{O}_{2}$," ACS Energy Lett., 4 [1] 352-7 (2018).

73. M. Zhu, C. Zhu, D. Wu, X. Wang, H. Wang, J. Gao, H. Huang, C. Shi, Y. Liu and Z. Kang, "Efficient Photocatalytic Water Splitting through Titanium Silicalite Stabilized CoO Nanodots," Nanoscale, 11 [34] 15984-90 (2019)

74. X. Shi, S. Siahrostami, G. L. Li, Y. Zhang, P. Chakthranont, F. Studt, T. F. Jaramillo, X. Zheng and J. K. Nørskov, "Understanding Activity Trends in Electrochemical Water Oxidation to Form Hydrogen Peroxide," Nat. Commun., 8 [1] 1-6 (2017).

75. K. Fuku and K. Sayama, "Efficient Oxidative Hydrogen Peroxide Production and Accumulation in Photoelectrochemical Water Splitting Using a Tungsten Trioxide/Bismuth Vanadate Photoanode," 


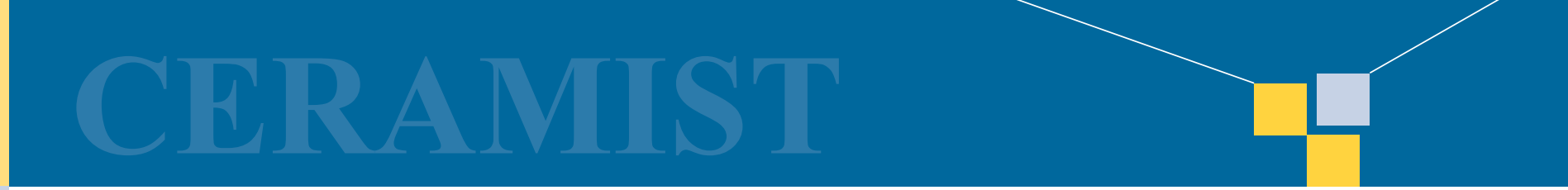

특 집 피 임성제, 김광희, 김성순, 박종혁

Chem. Commun., 52 [31] 5406-9 (2016).

76. K. Fuku, Y. Miyase, Y. Miseki, T. Gunji and K. Sayama, "Enhanced Oxidative Hydrogen Peroxide Production on Conducting Glass Anodes Modified with Metal Oxides," ChemistrySelect, 1 [18] 5721-6 (2016).

77. K. Fuku, Y. Miyase, Y. Miseki, T. Funaki, T. Gunji and K. Sayama, "Photoelectrochemical Hydrogen Peroxide Production from Water on a $\mathrm{WO}_{3} / \mathrm{BiVO}_{4}$ Photoanode and from $\mathrm{O}_{2}$ on an $\mathrm{Au}$ Cathode Without External Bias," Chem. Asian J., 12 [10] 1111-9 (2017).

78. T. H. Jeon, H. Kim, H. I. Kim and W. Choi, "Highly Durable Photoelectrochemical $\mathrm{H}_{2} \mathrm{O}_{2}$ Production via Dual Photoanode and Cathode Processes under Solar Simulating and External Bias-Free Conditions," Energy Environ. Sci., 6 [13] 1730-42 (2020).

79. S. Xie, Z. Shen, J. Deng, P. Guo, Q. Zhang, H. Zhang, C. Ma, Z. Jiang, J. Cheng, D. Deng and Y. Wang, "Visible Light-Driven $\mathrm{C}-\mathrm{H}$ Activation and $\mathrm{C}-\mathrm{C}$ Coupling of Methanol into Ethylene Glycol," Nat.
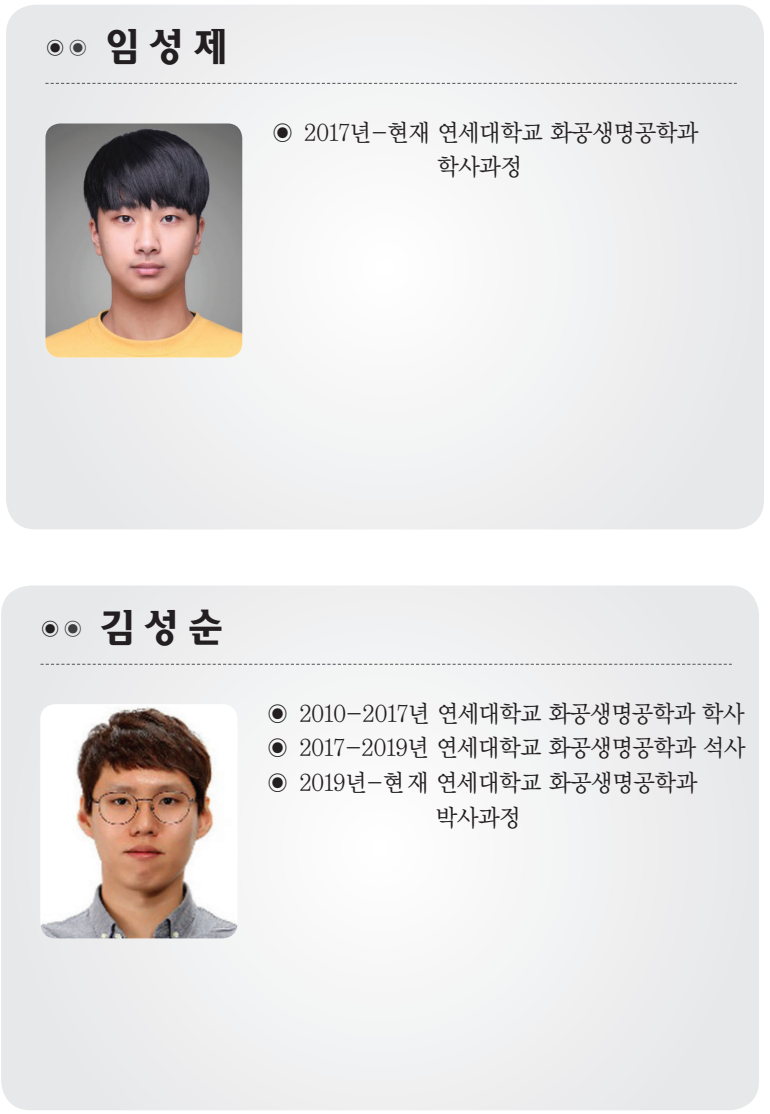

Commun., 9 [1] 1-7 (2018).

80. H. Zhang, S. Xie, J. Hu, X. Wu, Q. Zhang, J. Cheng and Y. Wang, "C-H Activation of Methanol and Ethanol and C-C Couplings into Diols by ZincIndium-Sulfide Under Visible Light," Chem. Commun., 56 [12] 1776-9 (2020).

81. H. Hao, L. Zhang, W. Wang, S. Qiao and X. Liu, "Photocatalytic Hydrogen Evolution Coupled with Efficient Selective Benzaldehyde Production from Benzyl Alcohol Aqueous Solution over $\mathrm{ZnS}-\mathrm{Ni}_{\mathrm{x}} \mathrm{S}_{\mathrm{y}}$ Composites," ACS Sustain. Chem. Eng., 7 [12] 10501-8 (2019).

82. N. Luo, T. Hou, S. Liu, B. Zeng, J. Lu, J. Zhang, H. Li and F. Wang, "Photocatalytic Coproduction of Deoxybenzoin and $\mathrm{H}_{2}$ through Tandem Redox Reactions," ACS Catal., 10 [1] 762-9 (2019).

83. D. Liu, J. C. Liu, W. Z. Cai, J. Ma, H. B. Yang, H. Xiao, J. Li, Y. J. Xiong, Y. Q. Huang and B. Liu, "Selective Photoelectrochemical Oxidation of Glycerol to High Value-Added Dihydroxyacetone," Nat. Commun., 10 [1] 1779 (2019).

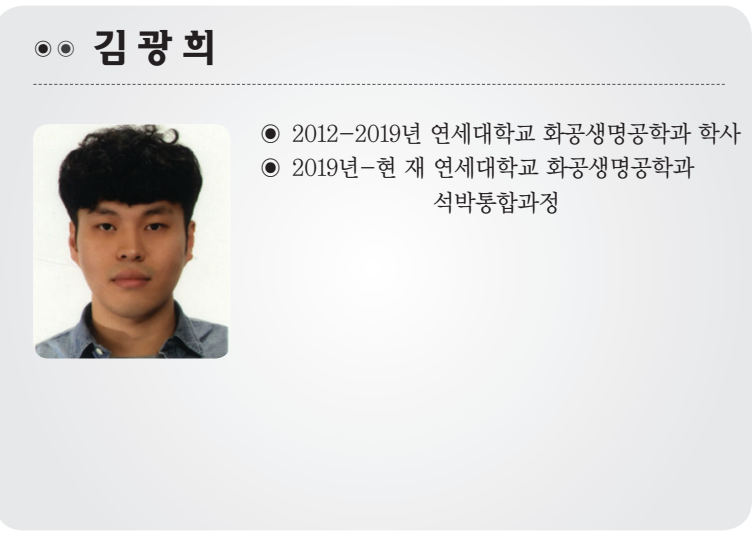

○박 종혁

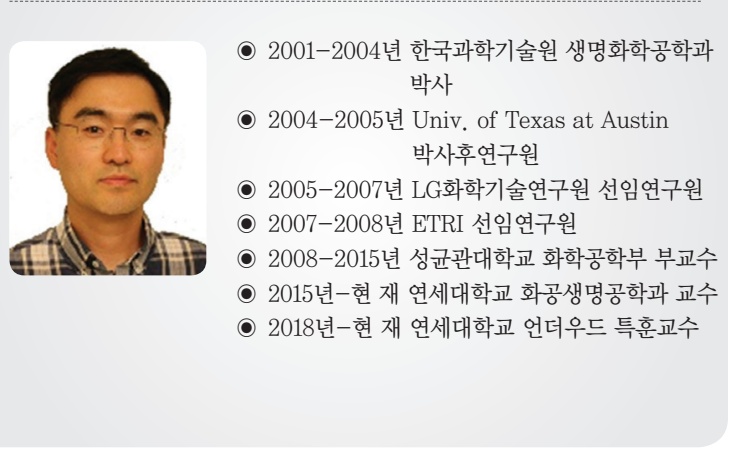

